\title{
Pengaruh Kecerdasan Emosional, Intelektual, Spiritual, Love Of Money Pada Sikap Mahasiswa Mengenai Etika Profesi Akuntan
}

\author{
Ida Bagus Putu Weda Pratama ${ }^{1}$ \\ Ida Bagus Putra Astika ${ }^{2}$ \\ ${ }^{1,2}$ Fakultas Ekonomi dan Bisnis Universitas Udayana (Unud), Bali, Indonesia \\ e-mail: wedapratama@yahoo.com
}

\begin{abstract}
ABSTRAK
Tujuan dari penelitian ini adalah untuk mendapatkan bukti empiris pengaruh kecerdasan emosional, kecerdasan intelektual, kecerdasan spiritual dan love of money pada sikap mahasiswa mengenai etika profesi akuntan. Pendekatan penelitian yang digunakan dalam penelitian ini adalah pendekatan kuantitatif dengan menggunakan data primer. Teknik sampling yang digunakan adalah nonprobability sampling dengan metode purposive sampling. Jumlah sampel yang digunakan dalam penelitian ini sebanyak 107 sampel. Teknik analisis yang digunakan adalah regresi linear berganda. Hasil penelitian ini menunjukan bahwa kecerdasan emosional, kecerdasan intelektual dan kecerdasan spiritual berpengaruh positif pada sikap mahasiswa mengenai etika profesi akuntan sedangkan love of money berpengaruh negatif pada sikap mahasiswa mengenai etika profesi akuntan. Implikasi praktis bagi mahasiswa bahwa mereka harus mempersiapkan sikap etis mereka sebelum mamasuki dunia kerja.
\end{abstract}

Kata kunci: Kecerdasan emosional, kecerdasan intelektual, kecerdasan spiritual, love of money, sikap mahasiswa mengenai etika profesi akuntan.

\begin{abstract}
The purpose of this study was to obtain empirical evidence of the influence of emotional intelligence, intellectual intelligence, spiritual intelligence and love of money on student attitudes regarding professional ethics of accountants. The research approach used in this study is a quantitative approach using primary data. The sampling technique used is nonprobability sampling with purposive sampling method. The number of samples used in this study were 107 samples. The analysis technique used is multiple linear regression. The results of this study indicate that emotional intelligence, intellectual intelligence and spiritual intelligence have a positive effect on student attitudes regarding professional ethics of accountants while love of money has a negative effect on student attitudes regarding professional ethics of accountants. Practical implications for students that they must prepare for their ethical attitude before entering the workforce.
\end{abstract}

Keywords: Emotional intelligence, intellectual intelligence, spiritual intelligence, love of money, student attitudes regarding professional ethics of accountants.

\section{PENDAHULUAN}

Lancarnya keberlangsungan praktik akuntansi tergantung pada beberapa hal penting yang salah satunya adalah tingkat kepercayaan yang diberikan oleh 
masyarakat kepada profesi. Ditemukannya isu etis yang terjadi di dunia eknomi dan bisnis setelah terjadi masalah mengenai kasus keuangan yang terjadi beberapa waktu belakangan (Normadewi, 2012). Kasus jatuhnya perusahaan Enron dan Arthur Anderson memiliki dampak yang sangat besar bagi dunia profesi akuntansi di seluruh dunia. Karena peristiwa tersebut, masyarakat lebih menyoroti kinerja akuntan. Meskipun lokasi kejadian dari kejadian tersebut terjadi di Amerika Serikat, orang-orang yang berada dalam ruang lingkup bidang akuntansi sangat merasakan pengaruh dari peristiwa tersebut (Clarke, Flanagan, \& O’Neill, n.d., 2011). Ditemukannya kasus akuntan yang memanipulasi laporan keuangan tidak hanya ditemukan di luar negeri namun juga ditemukan di dalam negeri yaitu kasus PT. KAI. Dengan ditemukannya banyak kasus mengenai manipulasi laporan keuangan oleh pihak yang berada di bidang akuntansi tentunya menurunkan rasa kepercayaan pihak-pihak terkait atas profesionalisme dari akuntan itu sendiri.

Sebelum menjadi seorang profesional dalam bidang akuntansi seseorang tentu perlu menempung jenjang pendidikan yang terfokus pada bidang akuntansi yaitu salah satunya sarjana akuntansi. Normadewi (2012) memiliki pendapat yaitu mahasiswa yang menempung jenjang pendidikan di bidang akuntansi pada masa sekarang adalah calon orang-orang professional bahwa mahasiswa akuntansi sekarang harus diberikan pendidikan mengenai etika karena mereka adalah para profesional di masa depan yang dapat mempengaruhi profesi yang ditekuninya. 
Svyantek (2003) berpendapat bahwa seseorang yang memiliki kecerdasan emosional maka orang tersebut dapat mengetahui bagaimana perasaan dirinya sendiri serta perasaan orang lain disekitarnya. Individu yang memiliki kecerdasan emosional akan memanfaatkan kemampuannya dalam memahami perasaan tersebut untuk mengendalikan pikirannya dalam bertindak agar tidak mengecewakan ataupun merugikan orang lain. Catarina $(2010 ; 24)$ berpendapat dengan kemampuan seseorang dalam mengatur emosinya dengan baik, individu tersebut akan memiliki motivasi untuk melakukan pengembangan terhadap potensi yang dimilikinya. Peningkatan potensi tersebut kemudian akan berdampak pada peningkatan kualitas dari sumber daya manusia.

Kecerdasan intelektual atau inteligensi adalah bagaimana individu menyesuaikan diri dengan keadaan yang terus berubah serta memiliki kerumitan yang tinggi. Robins \& Judge $(2008 ; 57)$ menyatakan bahwa seseorang yang memiliki kecerdasan intelektual mampu untuk mengendalikan pikirannya dan juga tindakannya dengan lebih rasional atau memiliki pemikiran atas pertimbangan dari tindakan yang dilakukannya.

Pengertian dari kecerdasan spiritual adalah kemampuan individu untuk mengembangkan dirinya ke arah yang lebih positif dengan dibantu kecerdasan jiwa. Menurut Zohar \& Marshall (2007) individu dalam melakukan tindakan tertentu, mempertimbangkan mengenai agama atau kepercayaan yang dipegang oleh individu tersebut. Tindakan tertentu tersebut dapat terkait dari bagaimana individu tersebut menyelesaikan masalah yang memerlukan kecerdasan spiritual dalam mengambil keputusannya. Individu yang dengan kecerdasan spiritual yang 
baik cenderung menggunakan pengalamannya sebagai penerapan bentuk dan nilai (Yanti, 2012). Kecerdasan sprititual yaitu individu tersebut memiliki kejujuran, terbuka, memiliki pengetahuan terhadap dirinya, dan memiliki pikiran yang terpusat pada kontribusi untuk dirinya (Setyawan, 2004). Dengan memiliki kecerdasan spiritual, individu cenderung memiliki cara berpikir yang lebih positif, keterbukaan akan wawasan, dan memberikan solusi untuk efisiensi suatu pekerjaan.

Uang dapat menjadi dasar yang mempengaruhi bagaimana sikap etis dari seseorang selain kecerdasan emosional, kecerdasan intelektual serta kecerdasan spiritual. Uang menjadi kebutuhan yang sangat diperlukan oleh manusia untuk keberlangsungan hidup mereka. Pentingnya peran uang di Amerika Serikat dapat dilihat dari bagaimana banyaknya uang menjadi penentu sukses tidaknya seseorang (Elias, 2010). Yang dimaksud Love of money adalah bagaimana sikap individu terhadap uang serta rasa ingin memiliki dan menjadikan uang sebagai motivasi (Luna-Arocas \& Tang, 2004). Setiap orang memiliki tingkat kecintaan pada uang yang berbeda-beda. Perbedaan ini didasari dari kebutuhan tiap manusia yang juga berbeda-beda.

Menurut Triandis (1971), teori sikap adalah bagaimana individu berperilaku berdasarkan sikap dan keinginannya, berdasarkan norma-norma sosial yang berlaku, berdasarkan bagaimana kebiasaan dari individu tersebut dengan memikirkan konsekuensi yang mungkin terjadi dari perilakunya. Notoatmodjo (2003) menyatakan bahwa perilaku adalah bagaimana rangsangan dari luar diri menimbulkan respon tertentu pada diri. Perilaku ialah hasil proses interaksi 
manusia dengan lingkungannya dan juga pengalamannya dimana terwujud dalam bentuk sikap, pengetahuan, serta tindakan (Green \& Kreuter, 2000)

Bagaimana individu bertindak kepada orang lain merupakan yang dimaksud dengan etika (Jusup, 2011). Bagaimana seseorang bertindak pada situsasi tertentu dengan didasari oleh pengalam-pengalaman dan segala pembelajaran yang telah dialami merupakan bagian dari etika (Tikollah, Triyuwono, \& Ludigdo, 2006).

Profesi adalah aktivitas secara intelektual mempelajari sesuatu baik secara formal maupun nonforma dan kemudian mendapatkan sertifikasi atas segala pelajaran yang telah ditempuh. Sertifikat yang diterbitkan merupakan sertifikat yang diterbitkan oleh organisasi atau badan yang secara spesifik berada pada bidang keilmuan tersebut dan bertanggungjawab atas kualitas dari lulusan tersebut (Kurniasari, 2018).

Menurut Goleman (2002) kecerdasan emosional adalah bagaimana individu memahami keadaan emosional pada dirinya sendiri dan memanfaatkannya kearah yang lebih positif. Individu dengan kecerdasann emosional cenderung akan lebih bijak. Kecerdasan emosional ini juga perlu dimiliki oleh mahasiswa. Mahasiswa yang memiliki kecerdasan emosional akan memiliki kejelasan mengenai pemahaman akan dirinya sendiri, lebih mengetahui motivasi dalam melakukan sesuatu, lebih mengerti atas tujuan apa yang akan dicapai, serta memiliki rasa peduli terhadap lingkungan sekitarnya yang kemudian akan meningkatkan keterampilan sosialnya. Serta kemampuannya untuk memahami suatu pelajaran atau ilmu yang salah satunya adalah ilmu akuntansi. 
Ida Bagus Putu Weda Pratama dan Ida Bagus Putra Astika. Pengaruh ...

Kecerdasan intelektual atau inteligensi adalah bagaimana individu menyesuaikan diri dengan keadaan yang terus berubah serta memiliki kerumitan yang tinggi. Robins \& Judge $(2008 ; 57)$ menyatakan bahwa seseorang yang memiliki kecerdasan intelektual mampu untuk mengendalikan pikirannya dan juga tindakannya dengan lebih rasional atau memiliki pemikiran atas pertimbangan dari tindakan yang dilakukannya.

Pengertian dari kecerdasan spiritual adalah kemampuan individu untuk mengembangkan dirinya kearah yang lebih positif dengan dibantu kecerdasan jiwa. Menurut Zohar \& Marshall (2007) individu dalam melakukan tindakan tertentu, mempertimbangkan mengenai agama atau kepercayaan yang dipegang oleh individu tersebut. Tindakan tertentu tersebut dapat terkait dari bagaimana individu tersebut menyelesaikan masalah yang memerlukan kecerdasan spiritual dalam mengambil keputusannya. Individu yang dengan kecerdasan spiritual yang baik cenderung menggunakan pengalamannya sebagai penerapan bentuk dan nilai (Yanti, 2012). Kecerdasan sprititual yaitu individu tersebut memiliki kejujuran, terbuka, memiliki pengetahuan terhadap dirinya, dan memiliki pikiran yang terpusat pada kontribusi untuk dirinya (Setyawan, 2004). Dengan memiliki kecerdasan spiritual, individu cenderung memiliki cara berpikir yang lebih positif, keterbukaan akan wawasan, dan memberikan solusi untuk efisiensi suatu pekerjaan.

Uang menjadi kebutuhan pokok bagi manusia dijaman sekarang Karen adengan uang manusia dapat memperoleh kebutuhan-kebutuhan yang diperlukan untuk bertahan hidup. Uang menjadi kebutuhan yang sangat diperlukan oleh 
manusia untuk keberlangsungan hidup mereka. Pentingnya peran uang di Amerika Serikat dapat dilihat dari bagaimana banyaknya uang menjadi penentu sukses tidaknya seseorang (Elias, 2010). Dalam penelitiannya Rubenstein, Harvey (1992) mengenai bagaimana anggapan masyarakat mengenai uang sebagai ukuran kesuksesan seseorang. Penelitian ini dilakukan di Amerika serikat dann tidak semuaorang beranggapan bahwa uang menjadi penentu dari kesuksesan dari seseorang.

Individu dalam melakukan sesuatu tentunya berdasarkan motivasi tertentu. Uang menjadi salah satu motivasi yang banyak muncul pada pikiran seseorang ketika melakukan sesuatu. Besarnya imbalan finansial dapat mempengaruhi bagaimana individu tersebut bekeja. Yang dimaksud dengan Love of money yaitu sikap individu terhadap uang serta rasa ingin memiliki dan menjadikan uang sebagai motivasi (Luna-Arocas \& Tang, 2004). Setiap orang memiliki tingkat kecintaan pada uang yang berbeda-beda. Perbedaan ini didasari dari kebutuhan tiap manusia yang juga berbeda-beda (Luna-Arocas \& Tang, 2004).

Beberapa penelitian sebelumnya yang mengambil topik hubungan antara kecerdasan emosional terhadap sikap etis dari mahasiswa akuntansi yaitu dilakukan oleh Agustini (2013) yang menemukan adanya hubungan yang positif antara kecerdasan emosional pada sikap etis mahasiswa akuntansi. Hasil yang sama juga ditemukan dalam penelitian yang dilakukan Lucyanda (2013) serta penelitian yang dilakukan oleh Fadli (2014). Ketiga peneitian tersebut menemukan bahwa kecerdasan emosional memiliki pengaruh yang positif terhadap sikap etis dari mahasiswa akuntansi. Hal ini berarti kecerdasan 
emosional yang dimiliki oleh mahasiswa akuntansi memiliki dampak pada bagimana mahasiswa terebut bertindak. Dengan mahasiswa akuntansi memiliki kecerdasan emosional maka mereka dapat mengontrol emosi yang mereka miliki sesuai dengan keadaan.

$\mathrm{H}_{1}$ : Kecerdasan emosional berpengaruh positif pada sikap mahasiswa mengenai etika profesi akuntan.

Penelitiaan sebelumnya yang mengangkat topik mengenai hubungan kecerdasan dari intelektual pada sikap etis mahasiswa jurusan akuntansi dilakukan oleh Tikollah et al. (2006) dan mendapatkan hasil adanya hubungan yang positif. Hasil yang sama juga ditemukan dalam penelitian yang dilakukan oleh Jamaluddin (2011) serta Agustini (2013). Ketiga penelitian menemukan bahwa kecerdasan intelektual memiliki hubungan yang positif terhadap sikap etis dari mahasiswa akuntansi. Mahasiswa akuntansi yang memiliki kecerdasan intelektual yang baik maka mampu memahami akuntansi dan dapat membaca dengan penuh pemahaman serta menunjukkan keingintahuan terhadap akuntansi.

$\mathrm{H}_{2}$ : Kecerdasan intelektual berpengaruh positif pada sikap mahasiswa mengenai etika profesi akuntan.

Beberapa penelitian sebelumnya yang mengambil topik hubungan antara kecerdasan spiritual terhadap sikap etis dari mahasiswa akuntansi yaitu dilakukan oleh Agustini (2013), Rochmah (2013) dan Wardana (2016). Ketika penelitian tersebut menemukan bahwa kecerdasan spiritual memiliki pengaruh yang positif terhadap sikap yang etis dari mahasiswa jurusan akuntansi.

$\mathrm{H}_{3}$ : Kecerdasan spiritual berpengaruh positif pada sikap mahasiswa mengenai etika profesi akuntan. 
Beberapa penelitian sebelumnya yang mengambil topik hubungan antara love of money terhadap sikap etis dari mahasiswa akuntansi yaitu dilakukan oleh Charismawati (2011), Normadewi (2012), Kurniawan (2017) dan Prabowo (2018) penelitian-penelitian sebelumnya menemukan bahwa love of money memiliki pengaruh yang negatif pada persepsi etis mahasiswa akuntansi. Semakin besar tingkat Love of Money mahasiswa maka akan semakin rendah sikap mahasiswa mengenai etika profesi akuntan.

$\mathrm{H}_{4}$ : Love of Money berpengaruh negatif pada sikap mahasiswa mengenai etika profesi akuntan.

Pendekatan kuantitaif dalam bentuk asosiatif diterapkan dalam penelitian ini. Yang dimaksud dengan metode kuantitatif adalah penelitian ini dilakukan berdasarkan kenyataan yang ada di lokasi penelitian serta memiliki sampel dan populasi penelitian. Pendekatan kuantitatif dalam bentuk asosiatif disini memiliki arti penelitian ini dilakukan berdasarkan kenyataaan dilokasi penelitian untuk mengetahui pengaruh dari variabel-variabel yang digunkan dalam penelitian ini (Sugiyono, 2017;64).

\section{METODE PENELITIAN}

Lokasi yang dipilih untuk penelitian ini adalah Program Magister (S2) di Fakultas Ekonomi dan Bisnis (FEB) Universitas Udayana yang berlokasi di wilayah Bali, Indonesia. Obyek penelitian adalah sifat dari obyek yang ditetapkan oleh peneliti untuk dipelajari dan kemudian memperoleh kesimpulan (Sugiyono, 2017;38). Objek dalam penelitian ini adalah mahasiswa Magister Akuntansi angkatan tahun 2017-2018 FEB Universitas Udayana. 
Ida Bagus Putu Weda Pratama dan Ida Bagus Putra Astika. Pengaruh ...

Penelitian ini memiliki satu variabel terikat yaitu sikap mahasiswa mengenai etika profesi akuntansi serta memiliki tiga variabel bebas yaitu pertama kecerdasan emosional, variabel bebas kedua adalah kecerdasan intelektual, variabel bebas ketiga adalah kecerdasan spiritual dan variabel bebas keempat adalah love of money.

Bagaimana individu bertindak kepada orang lain merupakan yang dimaksud dengan etika (Jusup, 2011). Bagaimana seseorang bertindak pada situsasi tertentu dengan didasari oleh pengalam-pengalaman dan segala pembelajaran yang telah dialami merupakan bagian dari etika (Tikollah et al., 2006). Tindakan individu yang sesuai dengan norrma-norma atau aturan-aturan yang berlaku baik tertulis maupun tidak tertulis merupakan sikap etis. Instrumen etika profesi akuntan diadopsi dari penelitian Kurniasari (2018) yang terdiri dari 10 pernyataan yang diukur dengan indicator Ethical Rating (ERATING). Pernyataan dan instrumen etika profesi akuntan diukur dengan menggunakan skala Likert empat poin, yaitu mulai dari 1 menyatakan (sangat tidak setuju) sampai 4 menyatakan (sangat setuju).

Menurut Goleman (2002) kecerdasan emosional adalah bagaimana individu memahami keadaan emosional pada dirinya sendiri dan memanfaatkannya kearah yang lebih positif. Individu dengan kecerdasann emosional cenderung akan lebih bijak. Svyantek (2003) berpendapat bahwa seseorang yang memiliki kecerdasan emosional maka orang tersebut dapat mengetahui bagaimana perasaan dirinya sendiri serta perasaan orang lain disekitarnya. Individu yang memiliki kecerdasan emosional akan memanfaatkan 
kemampuannya dalam memahami perasaan tersebut untuk mengendalikan pikirannya dalam bertindak agar tidak mengecewakan ataupun merugikan orang lain. (Catarina, 2010;24) berpendapat dengan kemampuan seseorang dalam mengatur emosinya dengan baik, individu tersebut akan memiliki motivasi untuk melakukan pengembangan terhadap potensi yang dimilikinya. Instrumen kecerdasan emosional diadopsi dari penelitian Aprilianto \& Achmad (2017) diukur dengan indikator, yaitu indikator yang pertama adalah bagaimana kesadaran dari diri, pengendalian terhadap diri, memotivasi diri, empati terhadap diri, keterampilan social yang dimiliki.

Kecerdasan intelektual atau inteligensi adalah bagaimana individu menyesuaikan diri dengan keadaan yang terus berubah serta memiliki kerumitan yang tinggi. Robins \& Judge $(2008 ; 57)$ menyatakan bahwa seseorang yang memiliki kecerdasan intelektual mampu untuk mengendalikan pikirannya dan juga tindakannya dengan lebih rasional atau memiliki pemikiran atas pertimbangan dari tindakan yang dilakukannya. Instrumen kecerdasan intelektual diadopsi dari penelitian Adinda (2015) yang terdiri dari 10 pernyataan yang diukur dengan indikator, yaitu, kemampuan memecahkan masalah, intelegensi verbal, intelegensi praktis

Menurut Zohar \& Marshall (2007) individu dalam melakukan tindakan tertentu, mempertimbangkan mengenai agama atau kepercayaan yang dipegang oleh individu tersebut. Tindakan tertentu tersebut dapat terkait dari bagaimana individu tersebut menyelesaikan masalah yang memerlukan kecerdasan spiritual dalam mengambil keputusannya. Individu yang dengan kecerdasan spiritual yang 
baik cenderung menggunakan pengalamannya sebagai penerapan bentuk dan nilai (Yanti, 2012). Kecerdasan sprititual yaitu individu tersebut memiliki kejujuran, terbuka, memiliki pengetahuan terhadap dirinya, dan memiliki pikiran yang terpusat pada kontribusi untuk dirinya (Setyawan, 2004). Instrumen kecerdasan spiritual diadopsi dari penelitian Fauzan (2016) yang terdiri dari 10 pernyataan yang diukur dengan indikator, yaitu mutlak jujur, keterbukaan, pengetahuan diri, fokus pada kontribusi, spiritual non-dogmatis

Proksi dari variabel love of money yang digunakan adalah Money Ethics Scale atau MES. MES sebelumnya dikembangkan oleh Luna-Arocas \& Tang (2004). Pengertian dari Love of money adalah sikap individu terhadap pada uang serta rasa ingin memiliki dan menjadikan uang sebagai motivasi (Luna-Arocas \& Tang, 2004). Setiap orang memiliki tingkat kecintaan terhadap uang yang berbeda-beda. Perbedaan ini didasari dari kebutuhan tiap manusia yang juga berbeda-beda. (Luna-Arocas \& Tang, 2004). Instrumen love of money diadopsi dari penelitian Harun (2016) yang terdiri dari 10 pernyataan yang diukur dengan indikator, yaitu, sikap positif, sikap negatif, pencapaian, kekuatan, pengelolaan uang, penghargaan.

Populasi dalam penelitian ini adalah mahasiswa Magister Akuntansi angkatan Tahun 2017-2018 FEB Universitas Udayana yang berjumlah 147 orang.

Sampel adalah bagian dari jumlah dan karakteristik yang dimiliki oleh populasi tersebut. Teknik pengumpulan sampel yang digunakan adalah metode purposive sampling. Purposive sampling merupakan teknik penentuan sampel dengan pertimbangan tertentu (Sugiyono, 2017;137). Kriteria yang digunakan 
ISSN: 2302-8556

E-Jurnal Akuntansi

Vol.28.1.Juli (2019): 351-376

untuk menentukan sampel dalam penelitian ini adalah mahasiswa Magister Akuntansi angkatan tahun 2017-2018 yang masih aktif kuliah.

Tabel 1.

Jumlah Mahasiswa Magister Akuntansi Tahun 2017-2018

\begin{tabular}{ccc}
\hline No & Tahun & $\begin{array}{c}\text { Jumlah Mahasiswa Magister } \\
\text { Akuntansi }\end{array}$ \\
\hline 1 & 2017 & 74 \\
2 & 2018 & 73 \\
& Total & 147 \\
\hline
\end{tabular}

Sumber: FEB Universitas Udayana, 2018

Teknik pengambilan sampel dalam penelitian ini adalah Teknik probability sampling yaitu random sampling. Metode random sampling yaitu pengambilan sampel populasi yang dilakukan secara acak tanpa memperhatikan strata yang ada dalam populasi tersebut.

Tabel 2.

Jumlah Sampel Pada Masing-masing Angkatan

\begin{tabular}{ccc}
\hline Tahun & Perhitungan & Hasil \\
\hline 2017 & $74 / 147 \times 107=53,8$ & 54 \\
2018 & $73 / 147 \times 107=53,1$ & 53 \\
& Total & 107 \\
\hline
\end{tabular}

Sumber: FEB Universitas Udayana, 2018

Dalam penelitian ini, peneliti mengumpulkan data dengan menggunakan kuesioner yaitu menyerahkan pertanyaan tertulis pada responden (Wiryono, 2011). Kuesioner disebarkan kepada mahasiswa Magister Akuntansi Tahun 20172018 menggunakan skala Likert empat poin.

Data kuantitatif merupakan jenis data yang digunakan. Jumlah responden yaitu mahasiswa Magister Akuntansi Tahun 2017-2018 Universitas Udayana yang mengisi kuesioner merupakan data kuantitatif penelitian. Sumber dari penelitian ini bersumber dari data primer. 


\section{HASIL DAN PEMBAHASAN}

Karakteristik responden yang diteliti meliputi umur, jenis kelamin dan angkatan yang berpartisipasi dalam pengisian kuesioner ini.

Tabel 3.

Karakteristik Responden Berdasarkan Umur

\begin{tabular}{lcc}
\hline Umur & Jumlah (orang) & $\%$ \\
\hline $20-30$ tahun & 87 & 81,30 \\
$31-40$ tahun & 20 & 18,70 \\
Total & 107 & 100 \\
\hline Sumber : Data diolah, 2019 & &
\end{tabular}

Berdasarkan Tabel 3 jumlah responden yang berumur 20-30 tahun mendominasi sebanyak 87 orang, sedangkan yang berumur 31-40 tahun berjumlah 20 orang.

Tabel 4.

Karakteristik Responden Berdasarkan Jenis Kelamin

\begin{tabular}{lcc}
\hline \multicolumn{1}{c}{ Jenis Kelamin } & Jumlah (orang) & $\%$ \\
\hline Laki-laki & 49 & 45,80 \\
Perempuan & 58 & 54,20 \\
Total & 107 & 100 \\
\hline
\end{tabular}

Sumber : Data diolah, 2019

Jumlah responden pada angkatan 2017 berjumlah 54 orang dan angkatan 2018 berjumlah 53 orang.

Tabel 5.

Karakteristik Responden Berdasarkan Angkatan

\begin{tabular}{|c|c|c|}
\hline Angkatan & Jumlah (orang) & $\%$ \\
\hline 2017 & 54 & 50,47 \\
\hline 2018 & 53 & 49,53 \\
\hline Total & 107 & 100 \\
\hline
\end{tabular}

Sumber : Data diolah, 2019

Uji validitas dilakukan dengan menghitung korelasi antara skor masingmasing butir pernyataan dengan total skor sehingga diperoleh nilai Pearson Correlation. 
ISSN: 2302-8556

E-Jurnal Akuntansi

Vol.28.1.Juli (2019): 351-376

Tabel 6.

Hasil Uji Validitas

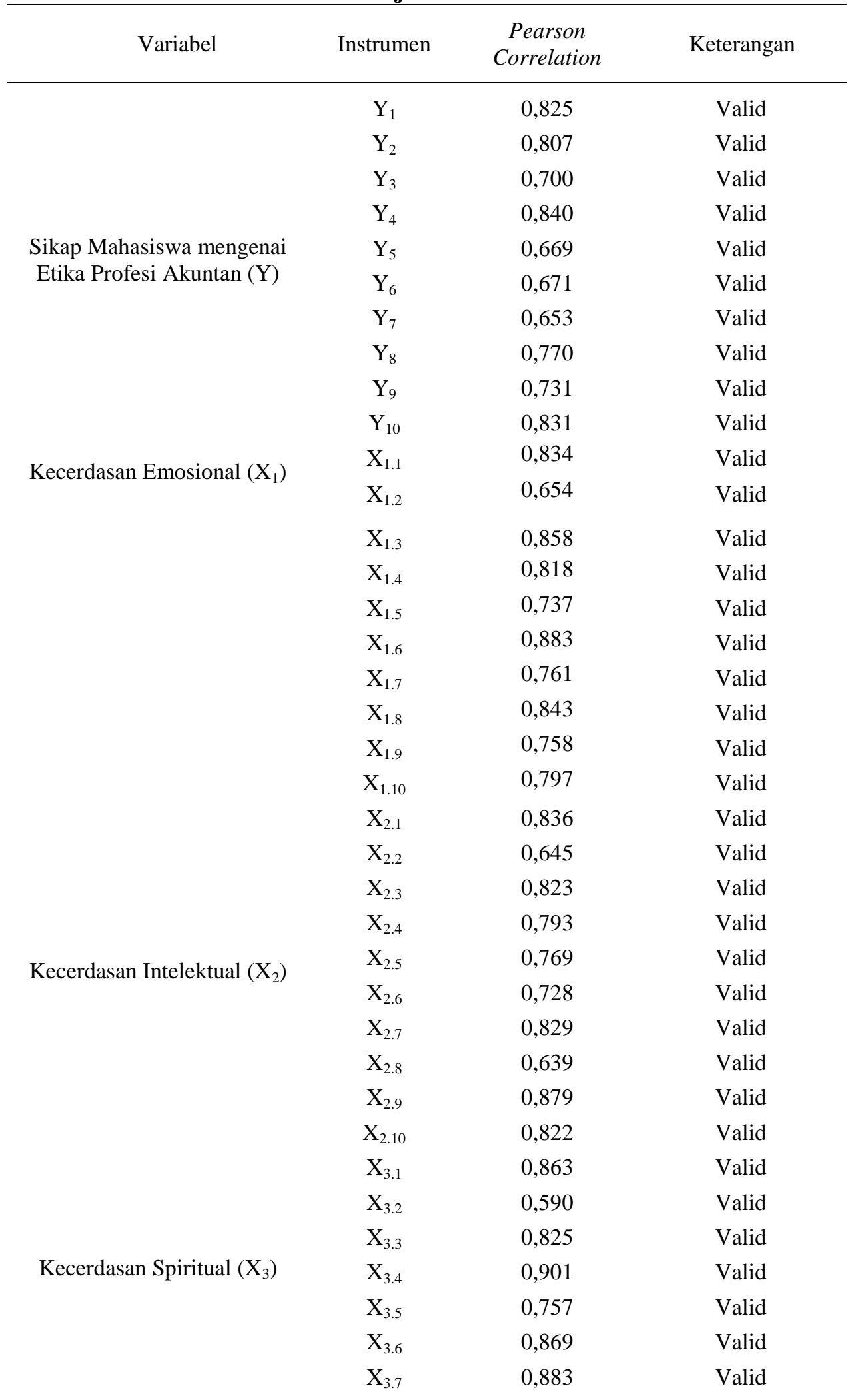


Ida Bagus Putu Weda Pratama dan Ida Bagus Putra Astika. Pengaruh ...

\begin{tabular}{cccc} 
& $\mathrm{X}_{3.8}$ & 0,630 & Valid \\
$\mathrm{X}_{3.9}$ & 0,843 & Valid \\
$\mathrm{X}_{3.10}$ & 0,828 & Valid \\
$\mathrm{X}_{4.1}$ & 0,891 & Valid \\
$\mathrm{X}_{4.2}$ & 0,786 & Valid \\
$\mathrm{X}_{4.3}$ & 0,886 & Valid \\
& $\mathrm{X}_{4.4}$ & 0,809 & Valid \\
Love of Money & $\mathrm{X}_{4.5}$ & 0,729 & Valid \\
$\left(\mathrm{X}_{4}\right)$ & $\mathrm{X}_{4.6}$ & 0,844 & Valid \\
& $\mathrm{X}_{4.7}$ & 0,807 & Valid \\
& $\mathrm{X}_{4.8}$ & 0,753 & Valid \\
$\mathrm{X}_{4.9}$ & 0,850 & Valid \\
$\mathrm{X}_{4.10}$ & 0,831 & Valid \\
\hline
\end{tabular}

Sumber : Data diolah, 2019

Hasil uji validitas yang disajikan pada Tabel 6 menunjukkan bahwa semua instrument penelitian yang digunakan untuk mengukur variabel penelitian memiliki Pearson Correlation diatas 0,3 sehingga dinyatakan valid.

Tabel 7.

Hasil Uji Reliabilitas

\begin{tabular}{lcc}
\hline \multicolumn{1}{c}{ Variabel } & Cronbach's Alpha & Keteranagan \\
\hline Sikap Mahasiswa mengenai Etika Profesi & & \\
Akuntan $(\mathrm{Y})$ & 0,908 & Reliabel \\
Kecerdasan Emosional $\left(\mathrm{X}_{1}\right)$ & 0,935 & Reliabel \\
Kecerdasan Intelektual $\left(\mathrm{X}_{2}\right)$ & 0,925 & Reliabel \\
Kecerdasan Spiritual $\left(\mathrm{X}_{3}\right)$ & 0,931 & Reliabel \\
Love of Money $\left(\mathrm{X}_{4}\right)$ & 0,944 & Reliabel \\
\hline Sumber : Data diolah, 2019 & &
\end{tabular}

Suatu instrumen dikatakan reliabel apabila instrumen tersebut mempunyai nilai Cronbach's Alpha lebih besar dari $0,7(>0,7)$. Hasil uji reliabilitas yang menunjukkan bahwa semua variabel yang digunakan dalam penelitian ini memiliki nilai koefisien yang melebihi 0,7 yang berarti semua variabel yang digunkan dalam penelitian ini reliable dan layak digunakan. 
ISSN: 2302-8556

E-Jurnal Akuntansi

Vol.28.1.Juli (2019): 351-376

Tabel 8.

Hasil Uji Statistik Deskriptif

\begin{tabular}{lccccc}
\hline \multicolumn{1}{c}{ Variabel } & $\mathrm{N}$ & Min. & Max. & Mean & Std. Deviation \\
\hline Sikap Mahasiswa mengenai Etika & 107 & 2 & 2,20 & 3,27 & 0,457 \\
Profesi Akuntan & & & & & \\
Kecerdasan Emosional & 107 & 2,20 & 4,00 & 3,3589 & 0,47741 \\
Kecerdasan Intelektual & 107 & 2,20 & 4,00 & 3,2897 & 0,49162 \\
Kecerdasan Spiritual & 107 & 2 & 4 & 3,34 & 0,494 \\
Love of Money & 107 & 1,60 & 4,00 & 2,9075 & 0,66993 \\
\hline
\end{tabular}

Sumber : Data diolah, 2019.

Berdasarkan hasil uji statistik deskriptif didapatkan bahwa variabel sikap mahasiswa mengenai etika profesi akuntan dengan jumlah sampel sebanyak 107 memiliki nilai minimum 2 dan maksimum 2,20 dengan rata-rata sebesar 3,27. Berdasarkan hasil uji statistik deskriptif didapatkan bahwa variabel kecerdasan emosional dengan jumlah sampel sebanyak 107 memiliki nilai minimum 2,20 dan maksimum 4,00 dengan rata-rata sebesar 3,35. Berdasarkan hasil uji statistik deskriptif didapatkan bahwa variabel kecerdasan intelektual dengan jumlah sampel sebanyak 107 memiliki nilai minimum 2,20 dan maksimum 4,00 dengan rata-rata sebesar 3,28. Berdasarkan hasil uji statistik deskriptif didapatkan bahwa variabel kecerdasan spiritual dengan jumlah sampel sebanyak 107 memiliki nilai minimum 2 dan maksimum 4 dengan rata-rata sebesar 3,34. Berdasarkan hasil uji statistik deskriptif didapatkan bahwa variabel love of money dengan jumlah sampel sebanyak 107 memiliki nilai minimum 1,60 dan maksimum 4,00 dengan rata-rata sebesar 2,90

Untuk mengetahui model regresi yang digunakan dalam penelitian ini telah berdistribusi normal atau tidak maka dilakukan uji normalitas. Untuk melihat hasil dari uji normalitas, dapat dilihat dari nilai Sig. yang dihasilkan. 
Tabel 9.

\section{Hasil Uji Normalitas}

\begin{tabular}{llr}
\hline & & Unstandardized Residual \\
\hline $\mathrm{N}$ & & 107 \\
Normal Paramters & Mean & 0,0000000 \\
& Std. Deviation & 0,23393059 \\
Most Extreme & Absolute & 0,059 \\
Difference & Positive & 0,059 \\
& Negative & $-0,050$ \\
Kolmogorov-Smirnov Z & & 0,609 \\
Asymp. Sig (2-tailed) & & 0,852 \\
\hline Sumber : Data diolah, 2019 & &
\end{tabular}

Setelah melakukan uji normalitas, didapatkan hasil bahwa model yang digunakan dalam penelitian ini berdistribusi normal. Hal tersebut dapat dilihat dari nilai Sig. yang telah melebihi 0,05 yaitu 0,852 .

Tabel 10.

Hasil Uji Multikolinearitas

\begin{tabular}{lcc}
\hline \multicolumn{1}{c}{ Variabel Penelitian } & Nilai Tolerance & Nilai VIF \\
\hline Kecerdasan Emosional $\left(\mathrm{X}_{1}\right)$ & 0,342 & 2,925 \\
Kecerdasan Intelektual $\left(\mathrm{X}_{2}\right)$ & 0,261 & 3,835 \\
Kecerdasan Spiritual $\left(\mathrm{X}_{3}\right)$ & 0,213 & 4,704 \\
Love of Money $\left(\mathrm{X}_{4}\right)$ & 0,854 & 1,171 \\
\hline Sumber : Data diolah, 2019 & &
\end{tabular}

Setelah melakukan uji normalitas, didapatkan hasil bahwa semua variabel yang digunakan dalam penelitian ini bebas dari multikolinearitas. Hal tersebut dapat dilihat dari nilai tolerance yang telah melebihi 0,10 .

Tabel 11.

Hasil Uji Heteroskedastisitas

\begin{tabular}{lcc}
\hline \multicolumn{1}{c}{ Variabel Penelitian } & Sig. & Keterangan \\
Kecerdasan Emosional $\left(\mathrm{X}_{1}\right)$ & 0,829 & Bebas Heteroskedastisitas \\
Kecerdasan Intelektual $\left(\mathrm{X}_{2}\right)$ & 0,701 & Bebas Heteroskedastisitas \\
Kecerdasan Spiritual $\left(\mathrm{X}_{3}\right)$ & 0,204 & Bebas Heteroskedastisitas \\
Love of Money $\left(\mathrm{X}_{4}\right)$ & 0,222 & Bebas Heteroskedastisitas \\
\hline
\end{tabular}


Setelah melakukan uji heteroskedastisitas, didapatkan hasil bahwa semua variabel yang digunakan dalam penelitian ini bebas dari heteroskedastisitas. Hal tersebut dapat dilihat dari nilai sig yang telah melebihi 0,05 .

Tabel 12.

Hasil Analisis Regresi Linier Berganda

\begin{tabular}{lccccc}
\hline \multirow{2}{*}{ Model } & \multicolumn{2}{c}{$\begin{array}{c}\text { Unstandarized } \\
\text { Coefficient }\end{array}$} & $\begin{array}{c}\text { Standardized } \\
\text { Coefficient }\end{array}$ & t & Sig. \\
\cline { 2 - 4 } & $\mathrm{B}$ & Std. Error. & Beta & & \\
\hline Constant & 0,791 & 0,247 & & 3,201 & 0,002 \\
$\mathrm{X}_{1}$ & 0,201 & 0,083 & 0,211 & 2,427 & 0,017 \\
$\mathrm{X}_{2}$ & 0,317 & 0,092 & 0,342 & 3,441 & 0,001 \\
$\mathrm{X}_{3}$ & 0,292 & 0,102 & 0,315 & 2,866 & 0,005 \\
$\mathrm{X}_{4}$ & $-0,075$ & 0,037 & $-0,111$ & $-2,017$ & 0,046 \\
Adjusted $\mathrm{R}_{\text {square }}: 0,727$ & & & & \\
$\mathrm{~F}_{\text {hitung }}:$ 71,720 & & & & \\
Sig F Fitung $: 0,000$ & & & & \\
\multicolumn{2}{l}{ Sumber : Data diolah, 2019} &
\end{tabular}

Berdasarkan Tabel 12 maka disusun persamaan regresi linier berganda sebagai berikut:

$$
Y=0,791+0,201 X_{1}+0,317 X_{2}+0,292 X_{3}-0,075 X_{4}
$$

Berdasarkan model regresi yang didapat yaitu sebesar 0,791 memiliki arti jika variabel kecerdasan emosional, kecerdasan intelektual, kecerdasan spiritual dan love of money dinyatakan konstan pada angka 0 , maka sikap mahasiswa pada etika profesi akuntan cenderung positif. Nilai $\beta_{1}$ untuk variabel kecerdasan emosional yaitu 0,201 berarti bahwa jika kecerdasan emosional meningkat maka akan menyebabkan peningkatan pada etika profesi akuntan, dengan asumsi variabel bebas lainnya dianggap konstan, Nilai $\beta_{2}$ untuk variabel kecerdasan intelektual yaitu 0,317 berarti bahwa jika kecerdasan intelektual meningkat maka akan menyebabkan peningkatan pada etika profesi akuntan, dengan asumsi variabel bebas lainnya dianggap konstan, Nilai $\beta_{3}$ untuk variabel kecerdasan spiritual yaitu 0,292 berarti bahwa jika kecerdasan spiritual meningkat maka akan 
menyebabkan peningkatan pada etika profesi akuntan, dengan asumsi variabel bebas lainnya dianggap konstan, Nilai $\beta_{4}$ untuk variabel love of money yaitu 0,075 berarti bahwa jika love of money meningkat maka akan menyebabkan penurunan pada etika profesi akuntan, dengan asumsi variabel bebas lainnya dianggap konstan.

Berdasarkan hasil analisis yang dilakukan dapat diamati mengenai uji kelayakan model (Uji F), koefisien determinasi $\left(R^{2}\right)$, dan nilai uji hipotesis (Uji t). Nilai $\mathrm{F}_{\text {hitung }}$ yang diperoleh adalah 71,720 dan memiliki nilai sigifikan sebesar 0,000. Dengan nilai signifikan sebesar 0,000 nilai tersebut lebih kecil dari 0,05 yang berarti maka model regresi yang digunakan dalam penelitian ini memenuhi syarat kelayakan model regresi.

Hasil analisis mendapatkan bahwa nilai Adjusted $R^{2}$ sebesar 0,727 yang berarti perubahan pada variabel sikap mahasiswa mengenai etika profesi akuntan dapat dijelaskan oleh kecerdasan emosional, kecerdasan intelektual, kecerdasan spiritual dan love of money sebesar $72,7 \%$ sedangkan sisanya dijelaskan oleh faktor lain yang tidak diuji dalam penelitian ini.

Setelah melakukan pengujian hipotesis pertama didapatkan hasil bahwa nilai koefisien regresi kecerdasan emosional sebesar 2,427 dan memiliki nilai signifikan sebesar 0,017 dimana lebih kecil dari 0,05. Dengan nilai signifikan yang dimiliki lebih kecil dari 0,05 maka hipotesis pertama diterima, artinya secara parsial kecerdasan emosional berpengaruh positif pada sikap mahasiswa mengenai etika profesi akuntan. berpegaruh positif disini memiliki arti bahwa semakin tinggi kecerdasan emosional mahasiswa akan mempengaruhi kemampuan mereka 
dalam menempatkan posisi dalam bersikap, mengenali dan mengelola emosi sehingga mahasiswa dapat bertindak sesuai norma dan nilai-nilai sikap yang berlaku dalam menjaga hubungannya di dunia kerja. Sesuai dengan penelitianpenelitian sebelumnya yang dilakukan oleh Agustini (2013), Lucyanda (2013), dan Fadli (2014) yang menemukan bahwa kecerdasan emosional memiliki pengaruh yang positif pada sikap etis mahasiswa akuntansi

Setelah melakukan pengujian hipotesis kedua didapatkan hasil bahwa nilai koefisien regresi kecerdasan intelektual sebesar 3,441 dan memiliki nilai signifikan sebesar 0,001 dimana lebih kecil dari 0,05. Dengan nilai signifikan yang dimiliki lebih kecil dari 0,05 maka hipotesis pertama diterima, artinya secara parsial kecerdasan intelektual berpengaruh positif pada sikap mahasiswa mengenai etika profesi akuntan. Berpengaruh positif disini berarti ketika kecerdasan intelektual mahasiswa meningkat maka akan berdampak positif pada persepsi mahasiswa tersebut mengenai sikap etis dari profesi akuntan. dengan meingkatnya kecerdasan intelektual, mahasiswa akan lebih bisa berpikir mengenai konsekuensi dari tindakannya, memikirkan jalan keluar dari suatu masalah, mengerti mengenai posisi dirinya, dapat mengambil keputusan dengan pertimbangan yang baik yang kemudian berdampak pada kinerjanya pada dunia kerja yang juga akan berdampak positif. Sesuai dengan penelitian-penelitian sebelumnya yang dilakukan oleh penelitian Tikollah et al. (2006), Jamaluddin (2011), dan Agustini (2013) yang menunjukkan bahwa kecerdasan intelektual memiliki pengaruh yang positif pada sikap etis mahasiswa akuntansi. 
Setelah melakukan pengujian hipotesis ketiga didapatkan hasil bahwa nilai koefisien regresi kecerdasan spiritual sebesar 2,866 dan memiliki nilai signifikan sebesar 0,005 dimana lebih kecil dari 0,05. Dengan nilai signifikan yang dimiliki lebih kecil dari 0,05 maka hipotesis pertama diterima, artinya secara parsial kecerdasan spiritual berpengaruh positif pada sikap mahasiswa mengenai etika profesi akuntan. berpengaruh positif disini berarti dengan meningkatnya kecerdasan spiritual mahasiswa maka akan dibarengi dengan semakin baiknya persepsi mahasiswa mengenai sikap etis dari profesi akuntan. peningkatan pada kecerdasan spiritual dapat berdampak pada keyakinan moral mahasiswa dalam menentukan suatu keputusan. Selain keyakinan moral, tingginya kecerdasan spiritual yang dimiliki seseorang akan membantu orang tersebut dalam mengontrol dirinya dan memiliki keyakinan bahwa segala pekerjaan yang dilakukannya merupakan salah satu bentuk dari ibadah sehingga terhindar dari perilaku menyimpang yang kemungkinan terjadi di dunia kerja. Sejalan dengan hasil dari penelitian-penelitian sebelumnya yang dilakukan oleh Agustini (2013), Rochmah (2013), dan Wardana (2016) yang menunjukkan bahwa kecerdasan spiritual memilliki pengaruh yang positif pada sikap etis mahasiswa akuntansi.

Setelah melakukan pengujian hipotesis keempat didapatkan hasil bahwa nilai koefisien regresi love of money sebesar -2,017 dan memiliki nilai signifikan sebesar 0,046 dimana lebih kecil dari 0,05. Dengan nilai signifikan yang dimiliki lebih kecil dari 0,05 maka hipotesis pertama diterima, artinya secara parsial love of money memiliki pengaruh yang negatif terhadap sikap mahasiswa mengenai etika profesi akuntan. berpengaruh negatif disini dimaksud adalah semakin tinggi 
ISSN: 2302-8556

E-Jurnal Akuntansi

Vol.28.1.Juli (2019): 351-376

kecintaan seseorang terhadap uang maka akan semakin rendah persepsinya mengenai sikap etis dalam profesi akuntan. individu dengan kecintaan terhadap uangnya yang tinggi hanya akan memikirkan uang sebagai dasar dalam melakukan kegiatan. Dengan hanya memiliki motivasi uang, individu tersebut akan mengabaikan aturan-aturan yang berlaku demi mendapatkan imbalan finansial yang lebih tinggi. Individu dengan love of money yang tinggi cenderung melakukan fraud untuk kepentingannya sendiri. Sesuai dengan hasil dari penelitian-penelitian sebelumnya yang dilakukan oleh Charismawati (2011), Normadewi (2012), Kurniawan (2017) dan Prabowo (2018) yang menunjukkan bahwa love of money memiliki pengaruh yang negatif pada sikap etis mahasiswa akuntansi.

\section{SIMPULAN}

Hasil dari penelitian ini menemukan bahwa kecerdasan emosional, kecerdasan intelektual, dan kecerdasan spiritual memiliki pengaruh yang positif pada sikap mahasiswa mengenai etika profesi akuntan. Berpengaruh positif disini berarti ketika kecerdasan emosional, kecerdasan intelektual, dan kecerdasan spiritual meningkat maka akan berdampak positif pada persepsi mahasiswa tersebut mengenai sikap etis dari profesi akuntan. sedangnkan Love of money memiliki pengaruh yang negatif pada sikap mahasiswa mengenai etika profesi akuntan. 


\section{REFRENSI}

Adinda, K. (2015). Pengaruh Kecerdasan Emosional dan Kecerdasan Intelektual Terhadap Perilaku Etis Mahasiswa Akuntansi Dalam Praktik Pelaporan Laporan Keuangan.

Agustini, S. (2013). Pengaruh Kecerdasan Intelektual, Kecerdasan Emosinal dan Kecerdasan Spiritual Terhadap Sikap Etis Mahasiswa S1 Akuntansi Universitas Pendidikan Ganesha Singaraja. Jurnal Ilmiah Mahasiswa Akuntansi S1 (JIMAT), 1(1), 1-12.

Aprilianto, R., \& Achmad, T. (2017). Pengaruh Kecerdasan Emosional, Kecerdasan Intelektual dan Love of Money terhadap Persepsi Mahasiswa Mengenai Etika Profesi Akutan.

Catarina. (2010). Pengaruh Kepemimpinan Transformasional dan Kecerdasan Emosional Terhadap Kinerja Karyawan. Jakarta: PT. Gramedia Pustaka Utama.

Charismawati, C. D. (2011). Analisis Hubungan antara Love of Moneydengan Persepsi Etika Mahasiswa Akuntansi. Jurnal Akuntansi.

Clarke, K., Flanagan, J., \& O’Neill, S. (n.d.). 2011. Winning ARC Grants: Comparing Accounting with Other Commerce-Related Disciplines. Accounting Research Journal, 213-244.

Elias, R. Z. (2010). The Relationship Between Accounting Students' Love of Money and Their Ethical Perception. Managerial Auditing Journal, 25(3).

Fadli, M. (2014). Pengaruh Kecerdasan Emosional, Kecerdasan Spiritual dan Kecerdasan Sosial Terhadap Sikap Etis Mahasiswa Akuntansi. Jurnal Ilmiah Mahasiswa FEB Universitas Brawijaya., 2(2), 2-17.

Fauzan, A. (2016). Pengaruh Kecerdasan Emosional, Kecerdasan Spiritual, dan Tekanan Klien Terhadap Kualitas Audit.

Goleman, D. (2002). Working with Emotional Intelligence. Jakarta: PT. Gramedia Pustaka Utama.

Green, L. W., \& Kreuter, M. . (2000). Health promotion planning an educational and environmental approach (2nd ed.). Mayfield Publishing Company.

Harun, F. (2016). Pengaruh Sifat Machiavellian dan Love of Money terhadap Perilaku Etis Auditor. Jurnal Ilmiah Akuntansi Peradaban.

Jamaluddin. (2011). Pengaruh Kecerdasan Intelektual, Kecerdasan Emosional, dan Kecerdasan Spiritual terhadap Etika Mahasiswa Akuntansi Fakultas 
Ekonomi Universitas Tadulako. Jurnal Ekonomi Dan Bisnis, 4(1), 46-56.

Jusup, A. H. (2011). Dasar-dasar Akuntansi. Yogyakarta: Bagian Penerbitan Sekolah Tinggi Ilmu Ekonomi YKPN.

Kurniasari, K. I. (2018). Pengaruh Kecerdasan Emosional, Kecerdasan Intelektual, Love of Money Pada Persepsi Mahasiswa Mengenai Etika Profesi Akuntan. E-Jurnal Akuntansi, 25(1), 773-798.

Kurniawan, P. I. (2017). Pengaruh Love Of Money dan Machiavellian Terhadap Persepsi Etis Mahasiswa Akuntansi. E-Jurnal Akuntansi, 21(3), 15-18.

Lucyanda, J. (2013). Faktor-Faktor Yang Mempengaruhi Perilaku Etis Mahasiswa Akuntansi Universitas Bakrie. Jurnal Ekonomi Dan Ilmu Sosial, 2(2), 1-34.

Luna-Arocas, R., \& Tang, T. L. P. (2004). The love of money, satisfaction, and the protestant work ethic: Money profiles among university professors in the U.S.A. and Spain. Journal of Business Ethics, 50(4), 329-354. https://doi.org/10.1023/B:BUSI.0000025081.51622.2f.

Normadewi, B. (2012). Analisis Pengaruh Jenis Kelamin dan Tingkat Pendidikan terhadap Persepsi Etis Mahasiswa dengan Love of Money sebagai Variabel Intervening. (Undergradu). Universitas Diponogoro.

Notoatmodjo, S. (2003). Pendidikan dan Perilaku Kesehatan. Jakarta: Rineka Cipta.

Prabowo, P. P. (2018). Pengaruh Love of Money, Machiavellian, Dan Idealisme Pada Persepsi Etis Mahasiswa Akuntansi. E-Jurnal Akuntansi, 23(1).

Robins, S. P., \& Judge, T. A. (2008). Organizational Behavior. US: Prentice Hall.

Rochmah, N. (2013). Pengaruh Kecerdasan Intelektual (IQ) dan Kecerdasan Spiritual (SQ) Terhadap Persepsi Mahasiswa Akuntansi Mengenai Keetisan Praktek Earnings Management. Jurnal Ilmiah Mahasiswa FEB Universitas Brawijaya., 1(2), 1-16.

Rubenstein, Harvey, M. (1992). Pedestrian Mall, Streetscapes and Urban Spaces. New York: John Wiley\&Sons.

Setyawan, D. (2004). Analisis pengaruh kepemimpinan (IQ, EQ, SQ) terhadap komitmen organisasional karyawan (Unpublishe). Semarang: Universitas Katolik Soegijapranata.

Sugiyono. (2017). Metodologi Penelitian Kuantitatif, Kualitatif, dan R\&D. Bandung: CV Alfabeta. 
Svyantek, D. . (2003). Emotional Intelligence and Organizational Behavior. The International Journal of Organizational Analysis, (11), 167-169.

Tikollah, R., Triyuwono, I., \& Ludigdo, U. (2006). Pengaruh Kecerdasan Intelektual, Kecerdasan Emosional dan Kecerdasan Spiritual Terhadap Sikap Etis Mahasiswa Akuntansi. Simposium Nasional Akuntansi (SNA) IX Padang, 23-28.

Triandis, H. C. (1971). Attitude and Attitude Change. Toronto: John Wiley and Sons.

Wardana, W. (2016). Pengaruh Kecerdasan Intelektual, Kecerdasan Emosional, Kecerdasan Spiritual, dan Gender Pada Sikap Etis Mahasiswa Magister Akuntansi Universitas Udayana. E-Jurnal Akuntansi, 5(10).

Wiryono, G. (2011). Merancang Penelitian Bisnis dengan Alat Analisis SPSS dan Smart PLS. Yogyakarta: UPP STIM YKPN.

Yanti, I. (2012). Pengaruh Kecerdasan Spiritual terhadap Kinerja Auditor Pada Kantor Akuntan Publik (Studi Empiris pada Provinsi Riau dan Sumatra Barat). Pekanbaru: Universitas Riau.

Zohar, D., \& Marshall, I. (2007). SQ: Kecerdasan Spiritual. (Rahmani Astusti, Ahmad Nadjib Burhani, Ahmad Baiquini. Terjemahan). Bandung: PT Mizan Pustaka. 